\title{
Modelling and Mapping of Critical Loads of Acidification and Eutrophication on Forest Ecosystems in Latvia
}

\author{
Iveta Steinberga, Faculty of Geography and Earth Science University of Latvia
}

\begin{abstract}
The Very Simple Dynamic model (VSD), which has been developed as the simplest extension of steady-state models, has been used for dynamic modelling of critical loads to forest ecosystems. The model consisting of a set of mass balance equations describes the soil input and output data relationships and fluxes, and soil properties. The mapping of critical loads of acidity and eutrophication effects is performed on 25562 deciduous, coniferous and mixed forest soil receptor polygons (area $>0.01 \mathrm{~km}^{2}$ ). The results have been mapped in the geographical units of EMEP grid $\left(50 \times 50 \mathrm{~km}^{2}\right)$.
\end{abstract}

Keywords - Atmospheric pollution, acidification, critical loads, eutrophication

\section{INTRODUCTION}

At the beginning of the 1980s the increasing damaging (e.g. defoliation) of forest trees was observed almost in all parts of Europe. Prevailing researches leading to the development of such scientific hypothesis blame air pollution as the main cause. Increasing emissions of nitrogen species into the atmosphere, long-range transport and deposition processes have been a persistent problem not only in Europe for quite a long time [1-6].

Relevant effects of acidification and eutrophication on ecosystems mostly include the following processes: (1) direct toxicity of nitrogen gases and aerosols, (2) accumulation of nitrogen compounds, which result in the increased nitrogen availability and changes in composition of species; (3) soil mediated acidification effects, and (4) increased susceptibility to secondary stress and disturbance factors such as drought, frost, pathogens and herbivores [7].

As the summarised effect, it could be assumed that the increasing nitrogen inputs may lead to biodiversity loss in terrestrial ecosystems $[6,8]$.

For the protection of the environment in Europe, specific targets - threshold values - have been defined. Critical loads are such threshold values. By definition, they are quantitative estimates of an exposure to a deposition of one or multi pollutants below which significant harmful effects on specific sensitive elements (e.g. forests, bogs, fishes, monuments) of the environment do not occur according to present knowledge. The 1999 Gothenburg protocol sets emission ceilings for 2010 for acidification and eutrophication processes responsible substances - nitrogen and sulphur, as well as for volatile organic compounds. The aforementioned emission ceilings were negotiated on the basis of assessment of critical loads and levels.
Critical load exceedances have been also used for managing emission reduction targets, which is a part of the UNECE Convention on Long-range Transboundary Air Pollution (LRTAP Convention) and the European Union air pollution abatement policy plans.

According to the land use data, forest ecosystems have been set as an indicator for describing acidification and eutrophication effects in Latvia.

Forests cover 3.1 million hectares or 48 percent of the total area of Latvia. During the last 90 years this percentage has had a stable trend of growth, e.g. the increase was from 24.7 percent in the early 1920 s to 48 percent in 2010 . The territorial distribution of forests in Latvia is not even. Areas with higher forest coverage are in the central part (Riga region), the southeast area (Cesis and Madona regions), as well as in the western parts (Ventspils, Liepaja, Talsi regions). Latvia's forests are regenerated either naturally or artificially. Natural regeneration of pine, spruce and deciduous species take place according to the site conditions on wet mineral and wet peat soils. Artificial rejuvenation involves the use of genetically improved seed and planting stock; forest seed orchards cover a total area of 10811 ha. The main forest tree species are: pine (914.5 thsd ha or $28.9 \%$ of total forest area); spruce (537.4 thsd ha or $17.0 \%$ of total forest area); birch (883.6 thsd ha or $27.0 \%$ of total forest area); asp (244 thsd ha or $7.7 \%$ of total forest area) [18].

Distribution of forest woodlands are shown in Fig. 1, and regional distribution of coniferous, broadleaved and mixed forests are shown in Fig. 2.

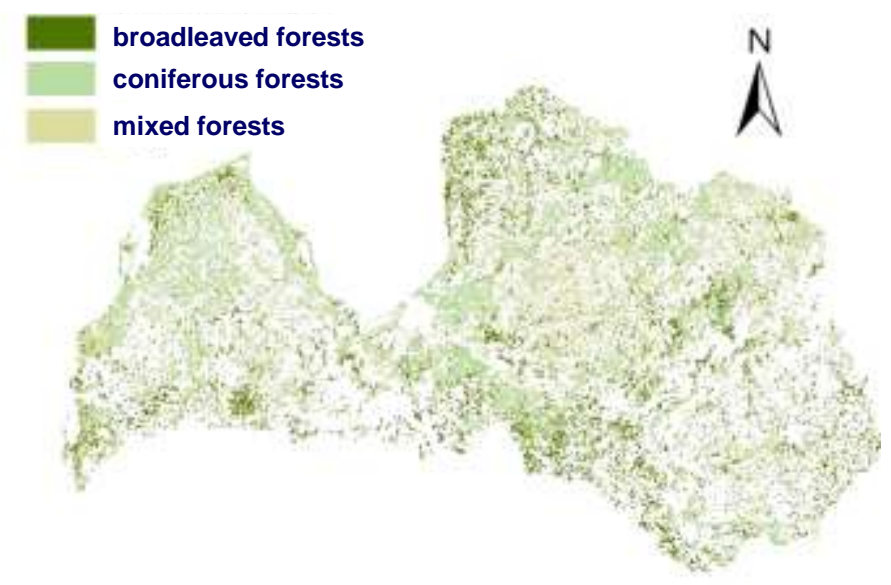

Fig.1. Shematic map of forest woodlands ditribution in Latvia [19]. 


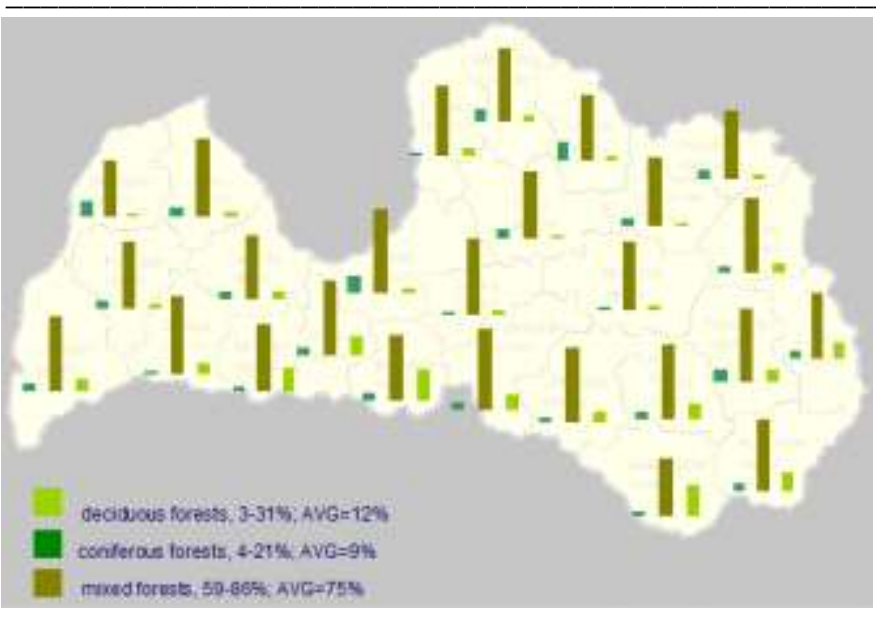

Fig.2. Shematic map of woodland types in Latvia [18].

The main objective of the study is to determine forest areas in Latvia which could be potentially damaged by acidification and eutrophication processes.

\section{MATERIALS AND METHODS}

The critical load approach has been developed and three different methods could be applied, each of them belonging to different level of sophistication - empirical, mass balance and critical load functional approach. The choice of a methodology depends mostly on the data availability.

The simple mass balance (SMB) method is the most commonly used model in Europe for the calculation of acidity critical loads for woodland ecosystems. This model is based on balancing acidic inputs and outputs in a system, to derive a critical load which ensures that a critical chemical limit (related to effects on the ecosystem) is not exceeded.

For this research, SMB method has been used. A generalization method of the data in EMEP geographical units has been used only for mapping, because of the regional scope, in order to harmonize the data on the European level. Critical loads have been calculated for each forest polygon; only very small polygons (area $<0.01 \mathrm{~km}^{2}$ ) were neglected.

\section{A. VSD model description}

The VSD model is a very simple dynamic model that simulates soil solution chemistry and soil nitrogen pools for natural or semi-natural ecosystems [9]. The overall VSD model is the simplest extension of the simple mass balance model that computes the maximum inputs of sulphur and nitrogen to an ecosystem that will not lead to harmful effects $[10,11]$.

The equations have been derived from a charge balance of ions in leaching fluxes from the soil compartment, combined with mass balance equations for the inputs, sinks, sources and outputs of sulphur and nitrogen [9, 17].

The aforementioned processes are described as a simple rate-limited reactions, first order processes and equilibrium reactions - nutrient uptake and weathering, denitrification, cation exchange.
VSD is a single-layer model, i.e., the soil is treated as a single homogeneous compartment. Furthermore, it is assumed that the soil depth is (at least) the depth of the rooting zone, which allows us to neglect the nutrient cycle and deal with net growth uptake only. Additional simplifying assumptions include: (a) all evapotranspiration occurs on the top of the soil profile, (b) percolation is constant through the soil profile and occurs only vertically, (c) physico-chemical constants are assumed uniform throughout the whole soil profile and (d) internal fluxes (such as the weathering rates, nitrogen immobilization etc.) are independent of the soil chemical conditions (such as $\mathrm{pH}$ ).

As the SMB model describes steady state conditions, it requires long-term averages for input fluxes. Short-term variations - e.g., episodic, seasonal, inter-annual, due to harvest and as a result of short-term natural perturbations - are not considered, but are assumed to be included in the calculation of the long-term mean. In this context, the 'longterm' is defined as about 100 years, i.e. at least one rotation period for forests. Ecosystem interactions and processes like competition, pests, herbivore influences etc. are not considered in the SMB model. Although the SMB model is formulated for undisturbed (semi-natural) ecosystems, the effects of extensive management, such as grazing and the burning of moor, could be included.

The charge balance links all ions considered in the VSD model:

$$
\begin{aligned}
\mathrm{H}^{+}+\mathrm{Al}^{3+}+\mathrm{BC}^{2+} & +\mathrm{Na}^{+}=\mathrm{SO}_{4}^{2-}+\mathrm{NO}_{3}^{-}+ \\
& +\mathrm{Cl}^{-}+\mathrm{HCO}_{3}^{-}+\mathrm{RCOO}
\end{aligned}
$$

where sum of $\mathrm{Ca}, \mathrm{Mg}$ and $\mathrm{K}$ is treated as a single ion $(\mathrm{BC}=$ $\mathrm{Ca}+\mathrm{Mg}+\mathrm{K}), \mathrm{Na}$ means sodium, $\mathrm{SO}_{4}$ sulphate, $\mathrm{NO}_{3}$ nitrate, $\mathrm{Cl}$ chloride and $R C O O$ the sum of organic anions. All concentrations are expressed in equivalents. The leaching of ammonium $\left(\mathrm{NH}_{4}\right)$ was neglected because of preferential uptake and complete nitrification within the root zone [4].

Some equilibrium reactions were included in VSD model dissolution of $\mathrm{Al}$ hydroxides, cation exchange and dissociation of bicarbonate and organic acids. Dissolution of Al hydroxides is calculated according to the following equation (known as Gibbsite equilibrium):

$$
A l=K_{g i b b} \cdot H^{3}
$$

where $K_{g i b b}$ is the gibbsite equilibrium constant. Concentration of bicarbonates is a function of the $\mathrm{pH}$ and dissociation of them is calculated via:

$$
\mathrm{HCO}_{3}=\frac{K_{1} \cdot K_{H} \cdot p_{\mathrm{CO} 2}}{H}
$$

where $K_{l}$ is the first dissociation constant, $K_{H}$ is Henry's constant and $p_{\mathrm{CO} 2}$ is the partial pressure of $\mathrm{CO}_{2}$ in the soil solution (in atm). Concerning dissociation of organic anions, all anions are assumed as monovalent and that only 
monovalent organic anions are produced by the dissociation of dissolved organic carbon:

$$
R C O O=\frac{m \cdot D O C \cdot K_{1}}{K_{1}+H}
$$

where $D O C$ is the concentration of dissolved organic carbon $\left(\mathrm{molC} / \mathrm{m}^{3}\right), \quad m$ is the concentration of functional groups $(\mathrm{mol} / \mathrm{molC})$ and $K_{l}$ the dissociation constant. Both parameters $D O C$ and $m$ are site-specific [5].

According to the fact that the value of $K_{I}$ does not always model the dissociation of organic acids properly, assessment of dissociation constant was done by Oliver equation [6]:

$$
p K_{1}=a+b \cdot p H-c \cdot(p H)^{2}
$$

where $a=0.96, b=0.90$ and $c=0.039$.

The exchange between the solid phase and soil solution is described for $A l, H$ and $B C(C a, M g$, and $K)$. For each of these cations and anions $\left(\mathrm{SO}_{4}, \mathrm{NO}_{3}\right.$, and $\left.\mathrm{Cl}\right)$, mass balance equations in VSD are described as:

$$
\frac{d X_{t o t}}{d t}=X_{i n}-Q \cdot X
$$

where $X_{\text {tot }}$ is the total amount of ion $X$ in the soil (in $\mathrm{eq} / \mathrm{m}^{2}$ ), $X_{\text {in }}$ describes the sum of all inputs from deposition and uptakerelease fluxes $\left(\mathrm{eq} / \mathrm{m}^{2} \cdot \mathrm{yr}\right), Q$ is the runoff (in $\mathrm{m} / \mathrm{yr}$ ).

Concerning $\mathrm{SO}_{4}, \mathrm{NO}_{3}, \mathrm{Na}$ and $\mathrm{Cl}$ interactions with the soil VSD assumes that the total amount of them equals the amount in the soil water:

$$
Y_{\text {tot }}=\theta \cdot z \cdot Y
$$

where $\mathrm{Y}$ is $\mathrm{SO}_{4}, \mathrm{NO}_{3}, \mathrm{Na}, \mathrm{Cl}, \mathrm{\theta}$ the water content in the soil (in $\mathrm{m}^{3} / \mathrm{m}^{3}$ ), and $z$ the thickness of the soil compartment (in $\mathrm{m}$ ).

Input fluxes in system for sulphate and chloride could be described as depositions alone:

$$
\begin{aligned}
& S O_{4 . i n}=S O_{2 . d e p} \\
& C l_{\text {in }}=C l_{\text {dep }}
\end{aligned}
$$

where dep describes total deposition. The fluxes for base cations are calculated by describing deposition and weathering:

$$
\begin{array}{r}
Y_{\text {in.Ca }, M g, K}=Y_{\text {dep.Ca,Mg, },}+z \cdot Y_{\text {we.Ca,Mg, },}- \\
-Y_{u \cdot C a, M g, K}
\end{array}
$$

where $Y_{\text {in. } C a, M g, K}$ is input fluxes of base cations in system, $Y_{\text {dep.Ca, } M g, K}$ deposition of base cations, $Y_{\text {we.Ca, } M g, K}$ the weathering rates of base cations, $Y_{u . C a}, M g, K-$ net growth uptake (all in eq $\left./\left(\mathrm{m}^{3} \cdot \mathrm{yr}\right)\right)$. The actual weathering rates for noncalcareous soils of depth $z$ (in $\mathrm{m}$ ) were calculated via:

$$
\begin{aligned}
B C_{w e} & =z \cdot 500 \cdot\left(W R_{c}-0,5\right) . \\
& \cdot \exp \left(\frac{A}{281}-\frac{A}{273+T}\right)
\end{aligned}
$$

where $W R c$ is the weathering rate class depending on the parent material and texture class, $T$ is the average annual soil temperature and $\mathrm{A}=3600 \mathrm{~K}[9]$.

The statement for critical loads of nutrient $\mathrm{N}$ calculation states to take account of all inputs and outputs of nitrogen, taking account of such processes as denitrification and leaching:

$$
N_{d e p}=N_{i}+N_{u}+N_{d e}+N_{l e}
$$

where $N_{d e p}$ is total $N$ deposition, $N_{i}$ the long-term net immobilization of $N$ in the soil organic matter, $N_{u}$ the net removal of $N$ in harvested vegetation and animals, $N_{d e}$ the flux of $N$ to the atmosphere due to denitrification, $N_{l e}$ the leaching of $N$ below the root zone.

In case by defining an acceptable limit to the leaching of $N$, $N_{\text {le(acc) }}$, equation (11) could be used for critical load of nutrient nitrogen $C L_{\text {nut }}(N)$ calculation:

$$
C L_{n u t}(N)=N_{i}+N_{u}+N_{d e}+N_{l e, a c c}
$$

In the simplest case, denitrification is linearly related to the net input of $N[8,12-15]$ :

$$
N_{d e}=f_{d e} \cdot\left(N_{d e p} \cdot N_{i}-N_{u}\right)
$$

if the $N_{d e p}>N_{i}+N_{u}$, else $N_{d e}=0$, where $f_{d e}\left(0<f_{d e}<1\right)$ is the denitrification fraction.

Nitrogen immobilization refers to the long-term net immobilization and accumulation in the root zone, and this process should not lead to significant changes in the prevailing $\mathrm{C} / \mathrm{N}$ ratio.

Nitrogen uptake flux $N_{u}$ equals the long-term average removal of $N$ from the ecosystem, and it depends on the harvesting practice. Basically, nitrogen uptake is calculated as a function of removed nitrogen $\left(\mathrm{N}_{\text {rem }}\right)$ and intervals between harvests $(T)$ :

$$
N_{u}=\frac{N_{r e m}}{T}
$$

The amount of nitrogen in the harvested biomass (stems and branches) is calculated as follows:

$$
\left.N_{r e m}=k_{g r} \cdot \rho_{s t} \cdot\left(c t N_{s t}+f_{b r, s t} \cdot c t N_{b r}\right)\right)
$$

where $k_{g r}$ is the average annual growth rate, $\rho_{s t}$ is the density of stem wood, ctN is the nitrogen content in stems and branches and $f_{b r, s t}$ is the branch-to-stem ratio.

The maximum critical load for acidity (sulphur) has been determined as follows: 


$$
\begin{array}{r}
C L_{\max }(S)=B C_{d e p}-C l_{d e p}+B C_{w}- \\
-B C_{u}-A N C_{l e, c r i t}
\end{array}
$$

where $\mathrm{ANC}_{\mathrm{le}, \mathrm{crit}}$ is the leaching of acid neutralizing capacity. If bicarbonates and organic anions do not contribute significantly at low $\mathrm{pH}, \mathrm{ANC}$ is determined as follows:

$$
A N C_{l e}=-Q \cdot(H+A l)
$$

where $Q$ is the precipitation surplus. The relationship between $[\mathrm{H}]$ and $[\mathrm{Al}]$ is described by gibbsite equilibrium [16].

$\mathrm{ANC}_{\mathrm{le}, \text { crit }}$ was determined by using critical base cation to proton ratio:

$$
A N C_{l e, c r i t}=0,5 \cdot \frac{B C_{d e p}+B C_{w}-B C_{u}}{(B C / H)_{c r i t}}
$$

where $(B c / H)$ crit is critical molar base cation to proton ratio. Values used for $(B c / H)$ crit are expressed as multiples of $(B c / A l) c r i t$, and these multiples ranging from 0.3 for deciduous forests and ground vegetation to 1 for spruce and pine [7]. The most commonly used value is $(B c / A l) c r i t=l$ (for the coniferous forests), for other types the critical $A l$ leaching is calculated from the leaching of $B c$ :

$$
A l_{l e, c r i t}=1,5 \cdot \frac{B c_{l e}}{(B c / A l)_{c r i t}}
$$

Finally, the maximum critical load of nitrogen is calculated as:

$$
C L_{\max }(N)=C L_{\text {min }}(N)+\frac{C L_{\text {max }}(S)}{1-f_{d e}}
$$

\section{B. Model input data}

Input to VSD model consists of a set of 24 parameters, listed in Table 1.

Calibration was done only for model process parameters, such as equilibrium constants, denitrification and immobilization fractions. The above mentioned parameters are uncertain, because estimates are very often based on limited (very small) data sets, and the most important parameters $(\mathrm{pH}$, $\mathrm{Al}, \mathrm{Bc}$, base saturation) are very sensitive to these processes parameters. Moreover, these parameters cannot be measured directly.

The thickness of the root zone was set to $50 \mathrm{~cm}$, a part of the soil data were obtained from measurements, and another part was theoretically calculated by using transfer functions. Hydrological and meteorological data, such as temperature, precipitation, evapotranspiration, were prepared by the Latvian Environment, Geology and Meteorology Center.

Deposition data were obtained from integrated monitoring sites. Integrated monitoring in Latvia has been started in 1985 at Rucava station. Description of integrated monitoring sites is given in Table 2.

Forest map of Latvia from Corine Land Cover was used to obtain information about forest types and density.

Data on harvesting practices were obtained from the State Forest Service annual reports.

The modelling and mapping of critical loads for acidification and eutrophication is based on 25562 deciduous, coniferous

\begin{tabular}{|c|c|c|c|c|c|c|c|}
\hline Parameter & Description & Calibration & Data source & Parameter & Description & Calibration & Data source \\
\hline thick & Thickness of the root zone & - & Soil data & f_de & Denitrification fraction & + & Assumption \\
\hline bulkdens & Bulk density & - & Soil data & percol & Precipitation surplus & - & Calculations \\
\hline theta & Soil water content & - & Calculations & BCwe & Base cations weathering & + & Calculations \\
\hline pCO2fac & $\begin{array}{l}\text { Partial pressure of } \mathrm{CO}_{2} \text { in } \\
\text { soil }\end{array}$ & - & Assumption & ctNst & $\begin{array}{l}\mathrm{N} \text { content in stems for } \mathrm{N} \\
\text { uptake }\end{array}$ & - & Calculations \\
\hline CEC & Cation exchange capacity & - & Calculations & ctCast & $\begin{array}{l}\text { Ca content in stems for } \mathrm{Ca} \\
\text { uptake }\end{array}$ & - & Calculations \\
\hline $\lg \mathrm{KAl} \operatorname{lox}$ & Equilibrium constant $\mathrm{H}-\mathrm{Al}$ & + & Assumption & Ca_dep & Ca deposition & - & Measurements \\
\hline $\lg \mathrm{AlBc}$ & Exchange constant Al-BC & + & Assumption & $\mathrm{SO}_{2 \_}$dep & $\mathrm{SO}_{2}$ deposition & - & Measurements \\
\hline $\lg \mathrm{KHBc}$ & Exchange constant H-BC & + & Assumption & NOx_dep & NOx deposition & - & Measurements \\
\hline Nim_acc & $\mathrm{N}$ immobilization & + & Calculations & Mg_dep & Mg deposition & - & Measurements \\
\hline Cpool_0 & Initial C poll & - & Calculations & K_dep & $\mathrm{K}$ deposition & - & Measurements \\
\hline CNrat_0 & Initial $\mathrm{CN}$ ratio & - & Calculations & Na_dep & Na deposition & - & Measurements \\
\hline cRCOO & Organic anion concentration & - & Assumption & Cl_dep & $\mathrm{Cl}$ deposition & - & Measurements \\
\hline
\end{tabular}
and mixed forest soil receptor polygons (area $>0.01 \mathrm{~km}^{2}$ ). The results have been aggregated for the geographical units of the $\operatorname{EMEP}\left(50 \cdot 50 \mathrm{~km}^{2}\right)$ grid.

TABLE I

VSD MODEL INPUT PARAMETERS 
TABLE 2

INTEGRATED MONITORING SITES DESCRIPTION

\begin{tabular}{|l|l|l|}
\hline Station & Rucava & Zoseni \\
\hline Established & 1985 & 1994 \\
\hline Coordinates & $\begin{array}{l}56^{\circ} 09^{\prime} 41^{\prime \prime} \\
21^{\circ} 10^{\prime} 23^{\prime \prime}\end{array}$ & $\begin{array}{l}57^{\circ} 08^{`} 06^{\prime \prime} \\
25^{\circ} 54^{\prime} 20^{\prime \prime}\end{array}$ \\
\hline Elevation, m & 18 & 183 \\
\hline $\begin{array}{l}\text { Annual average } \\
\text { precipitation, mm }\end{array}$ & 772 & 727 \\
\hline $\begin{array}{l}\text { Annual average } \\
\text { temperature, }{ }^{\circ} \mathrm{C}\end{array}$ & +6.3 & +4.5 \\
\hline $\begin{array}{l}\text { Predominant wind } \\
\text { direction }\end{array}$ & $\mathrm{SW}, \mathrm{SE}$ & $\mathrm{SW}$ \\
\hline $\begin{array}{l}\text { Annual average } \\
\text { velocity of wind, m/s }\end{array}$ & 4.2 & 2.8 \\
\hline $\begin{array}{l}\text { Duration of stable snow } \\
\text { cover, days }\end{array}$ & 72 & 126 \\
\hline Sunshine period, h/yr & 1874 & 1622 \\
\hline $\begin{array}{l}\text { Duration of vegetation } \\
\text { period, days }\end{array}$ & 198 & \\
\hline
\end{tabular}

\section{RESULTS}

Critical loads have been calculated using data derived from GIS maps. Critical loads of nitrogen and sulphur have been compared to the actual atmospheric deposition and exceedances evaluated. A deterministic critical load assessment is based on the principle that the deposition of sulphur, oxidized and reduced nitrogen deposition should not exceed the critical load. But it should be recognized that there is uncertainty in the deposition (and the critical load).

The calculated values for critical loads of sulphur and nitrogen give a good initial indication of the spatial variability of the ecosystem sensitivity to acidification in Latvia.

The low values of base cations deposition, due to precipitation together with other parameters, lead to high values of the critical loads for the acidifying pollutants. The calculated values for $\mathrm{CL}_{\max }(\mathrm{S})$ vary between 734 and $8782 \mathrm{eq} /(\mathrm{ha} \cdot \mathrm{yr})$ for deciduous, coniferous and mixed forests. Critical load values for eutrophication $\left(\mathrm{CL}_{\max }(\mathrm{N})\right)$ are much higher, ranging from 2419 to $25497 \mathrm{eq} /(\mathrm{ha} \cdot \mathrm{yr})$, and, for nutrient nitrogen $\left(\mathrm{CL}_{\text {nut }}(\mathrm{N})\right)$, between 107 and $680 \mathrm{eq} /(\mathrm{ha} \cdot \mathrm{yr})$.

The dominating $\mathrm{CL}_{\max }(\mathrm{S})$ values of $63 \%$ are in the range from 4301 to $4800(\mathrm{eq} /(\mathrm{ha} \cdot \mathrm{yr}))$, but only $0.4 \%$ of them are very high (ranges between 5301 to 5700 (eq/(ha·yr))), see Fig. 3.

More than $50 \%$ of $\mathrm{CL}_{\max }(\mathrm{N})$ values vary between 12901 and $13900 \mathrm{eq} /(\mathrm{ha} \cdot \mathrm{yr})$, see Fig. 4, which means that more than $50 \%$ of forest ecosystems have a high buffer capacity against eutrophication effects.

About $44 \%$ of $\mathrm{CL}_{\text {nut }}(\mathrm{N})$ values vary between 201 and 300 eq/(ha. yr), see Fig. 5.

The highest $\mathrm{CL}_{\max }(\mathrm{S})$ and $\mathrm{CL}_{\max }(\mathrm{N})$ values detected in the central part of Latvia (EMEP grid cell 66/71 close to the capital city - Riga) and in the western part of Latvia (EMEP grid cell 64/68 - Ventspils region). Such values could be explained by high base cation deposition values and high depositions of sulphur and nitrogen as well.

Significant differences in critical loads have been detected in different types of woodlands. The highest $\mathrm{CL}_{\max }(\mathrm{S})$ values have been found in broadleaved forests $(800-8782$ (eq/(ha.yr)) in the central and western parts of Latvia (EMEP cell grids $66 / 71 ; 64 / 68)$.

Overall critical loads for acidification in Latvia have not been exceeded. A much higher potential for the ecosystem degradation and acidification exists in the eastern part of Latvia.

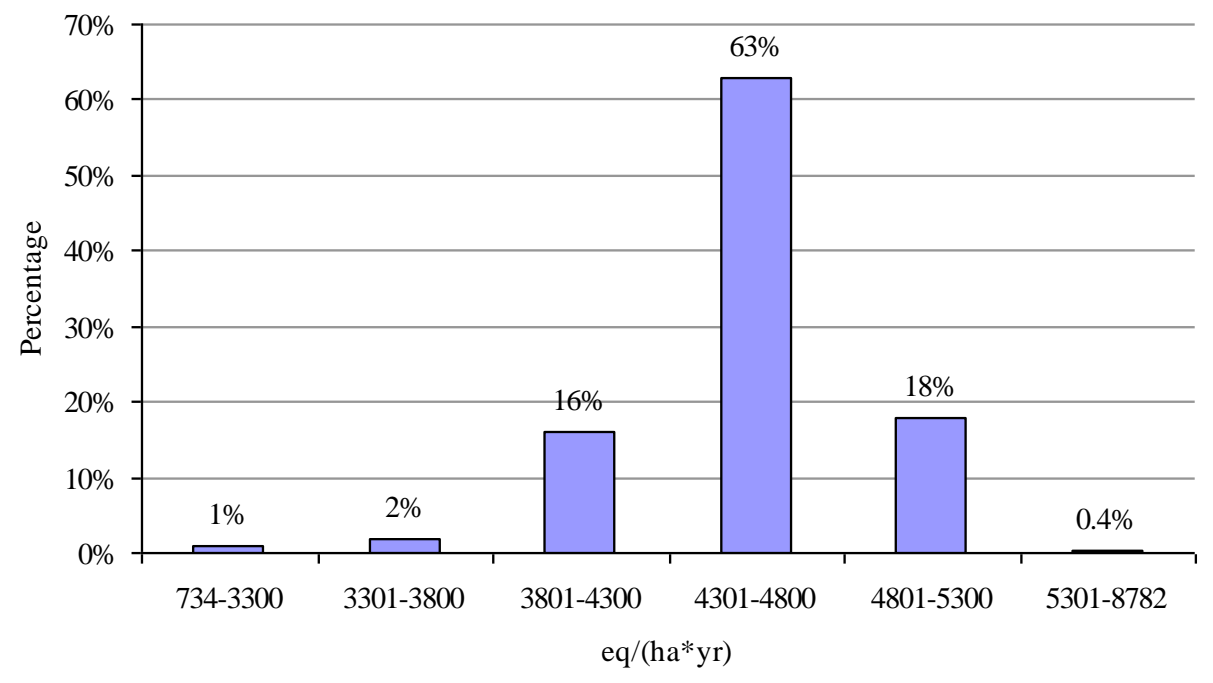

Fig.3. Distribution of $\mathrm{CL}_{\max }(\mathrm{S})$ critical loads in forest polygons in Latvia 


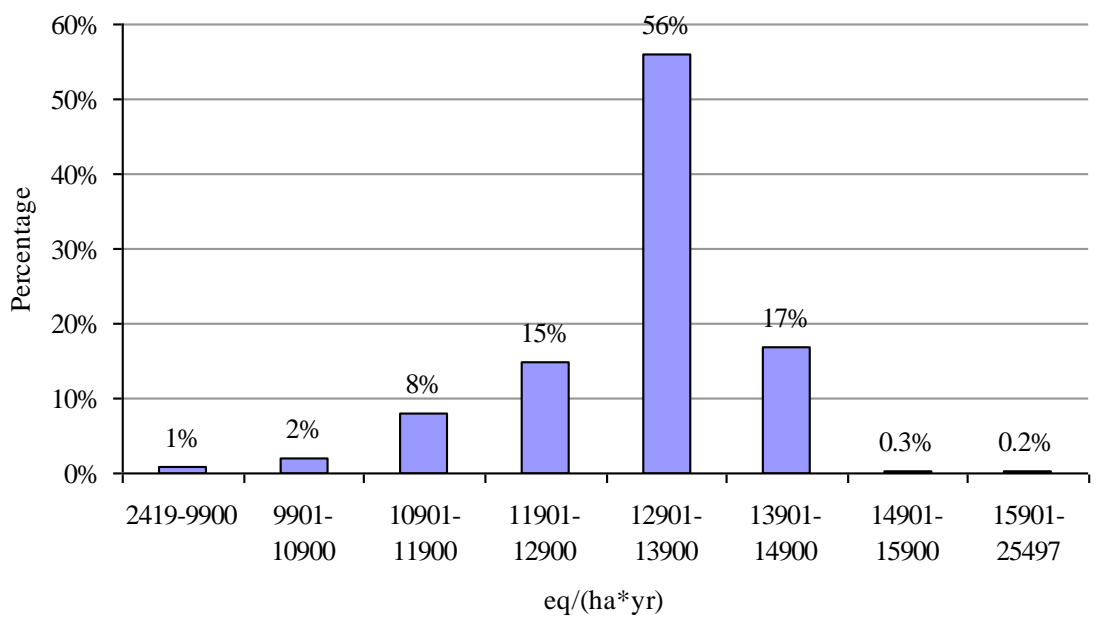

Fig.4. Distribution of $\mathrm{CL}_{\max }(\mathrm{N})$ critical loads in forest polygons in Latvia.

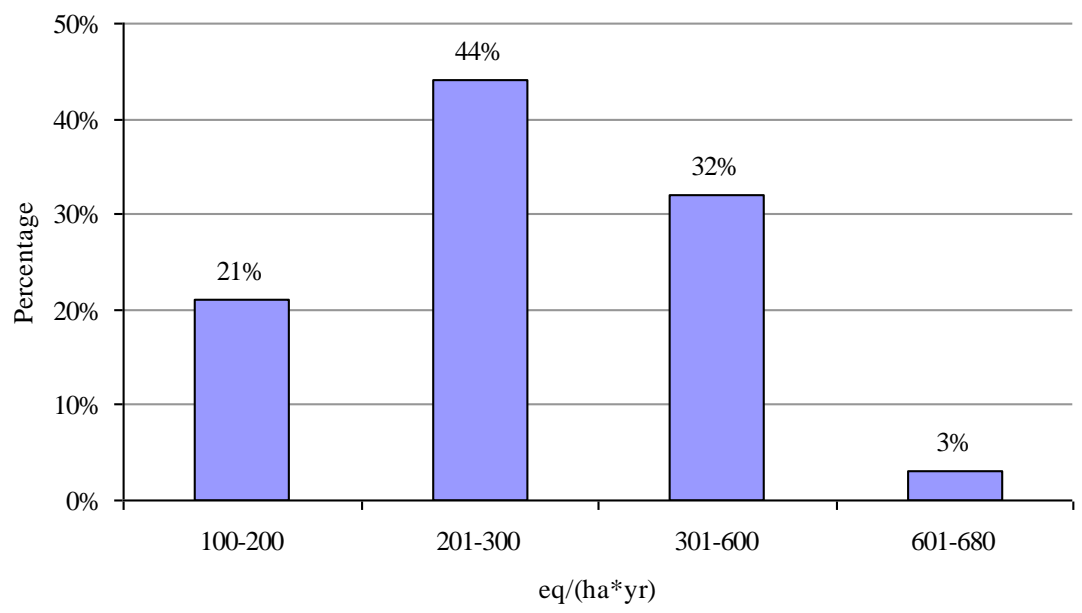

Fig.5. Distribution of $\mathrm{CL}_{\mathrm{nut}}(\mathrm{N})$ critical loads in forest polygons in Latvia.

\section{CONCLUSIONS}

Since the negative influence of nitrogen in all ecosystems becomes worse (loss of biodiversity), it is valuable to calculate critical loads also for the nitrogen sensitive non-forest ecosystem, such as raised bogs in Latvia, also to protect and monitor this very sensitive ecosystem in the future.

Calculation of critical loads of heavy metals (mercury, cadmium, lead) also has high priority, especially with regard to mercury. The accumulation of mercury, especially in the ecosystems of Nordic countries, is becoming a serious problem. It can be expected that the critical loads of mercury in Latvia are exceeding, due to the hydro biological and geological circumstances (wet lands, high organic carbon content in sediments).

According to the data, calculations and simulations, critical loads for acidification in Latvia are high. The Critical Loads for acidification are not exceeded in any Latvian area. Therefore, acidification does not seem to be a problem in the future.
The situation for eutrophication is similar, and there is no evidence for exceedances as yet.

\section{REFERENCES}

1. Grennfelt, P., Thörnelöf, E. (Eds). Critical loads for nitrogen. In: Report from a Workshop held in Lökeberg, Sweden, April 6-10, 1992. Copenhagen, 1992, p. 428.

2. Gundersen, P., Emmett, B.A., Kjonaas, O.J., et al. Impact of nitrogen deposition on nutrient cycling in forests: a synthesis of NITREX data. Forest Ecology and Management, 1998, N 101, p. 37-56.

3. Erisman, J.W., de Vries, W. Nitrogen deposition and effects in European forests. Environmental Reviews, 2000, N 8, p. 65-93.

4. Aber, J.D., Goodale, C.L., Ollinger, S.V., et al. Is nitrogen deposition altering the nitrogen status of North-eastern forests? BioScience, 2003, vol. 4, N 53, p. 375-389.

5. Galloway, J.N., Aber, J.D., Erisman, J.W., et al. The Nitrogen Cascade. BioScience, 2003, vol. 4, N 53, p. 341-356.

6. Matson, P., Lohse, K.A., Hall, S.J. The globalization of nitrogen deposition: consequences for terrestrial ecosystems. Ambio, 2003, vol. 2, N 31, p. 113-119.

7. Achermann, B., Bobbink, R. (Eds.). Empirical Critical Loads for Nitrogen. In: Proceedings of an Expert Workshop held in Bern, Switzerland, November, 2002. Bern, 2003, p.325.

8. De Vries, W., Kros, H., Reinds, G.J., et al. Developments in deriving critical limits and modelling critical loads of nitrogen for terrestrial 
ecosystems in Europe. In: Alterra Report 1382. The Netherlands, 2007, p. 206.

9. Posch, M., Hettelingh, J.-P., Slootweg, J. Manual for dynamic modelling of soil response to atmospheric deposition. Bilthoven, 2003, $315 \mathrm{p}$.

10. Posch, M., De Vries, W. Derivation of critical loads by steady-state and dynamic soil models. Kluwer : Dordrecht, 1999, p. 213-234.

11. De Vries, W., Posch, M. Critical levels and critical loads as a tool for air quality management. In: Handbook of Atmospheric Science. Principles and Applications. Blackwell Science, Oxford, UK, 2003, p. 562-602.

12. De Vries, W., Reinds, G.J., Posch, M., et al. Intensive monitoring of forest ecosystems in Europe. In: Technical report 2003. Forest Intensive Monitoring Coordinating Institute (FIMCI), EC-UNECE, Brussels, Geneva, 2003, p. 161.

13. Driscoll, C.T., Fuller, R.D., Schecher, W.D. The role of organic acids in the acidification of surface waters in the eastern U.S. Water, Air and Soil pollution, 1989, N 43, p. 21-40.

14. Oliver, B.G., Thurman, E.M., Malcolm, R.L. The contribution of humic substances to the acidity of coloured natural waters. Geochimica et Cosmochimica Acta, 1983, N 47, p. 2031-2035.

15. Evans, C.D., Caporn, S.J.M., Carroll, J.A., et al. Modelling nitrogen saturation and carbon accumulation in heatland soils under elevated nitrogen deposition. Environmental Pollution, 2006, N 143, p. 468-478.

16. Posch, M., Slootweg, J., Hettelingh, J.P. (Eds.). European Critical Loads and Dynamic Modelling. In: RIVM Report No. 259101-16, 2005, p. 45 .

\section{Iveta Šteinberga. Kritisko slodžu aprēḳini un kartēšana uz mežu apgabaliem Latvijā}

Kritiskā slodze (CL) ir viena vai vairāku piesārņojošo vielu ietekmes novērtējums, kas var radīt kaitējumu noteiktiem vides jutīgajiem elementiem, ņemot vērā esošās zināšanas. To aprēķināšanā tiek ņemti vērā ne tikai mērḳekosistēmu raksturojoši parametri, bet arī tās eksistenci un labsajūtu nodrošinošo parametru ilgtermina izmainas.

CL modelēšana veikta mežu apgabaliem Latvijā izmantojot VSD (Very Simple Dynamic model) masas bilances modeli. Mežu apgabali izvēlēti kā Latvijas teritoriju raksturojošs indikators paskābināšanās un eitrofikācijas procesu novētēejumam.

Kritisko slodžu aprēḳināšanai nepieciešamie dati nosacīi iedalāmi 5 pamatblokos: (1) augsnes kvalitāti raksturojoši dati; (2) mežu stāvokli un apsaimniekošanas

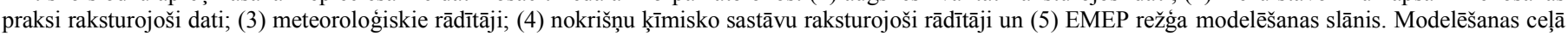
tika iegūti rezultāti 25562 mežu poligoniem: (1) maksimālā slāpekḷa kritiskā slodze svārstījās robežās no 2419-25497 eq/(ha×a); (2) maksimālā sēra kritiskā slodze svārstījās robežās no 734-8782 eq/(ha×a). Modẹ̦a kalibrēšana veikta izmantojot augsnes ķ̣imiskā sastāva rādītājus, papildus tika veikta starprobežu rezultātu salīdzināšana.

Galvenie secinājumi: (1) nnemot vērā slāpekḷa savienojumu nelabvēlīgo ietekmi uz dažādām ekosistēmām, būtu nepieciešams veikt līdzīga tipa modelěšanu cita veida jutīgām ekosistēmām, piemēram, purviem, (2) smago metālu kritisko slodžu modelēšana uzskatāma par nākotnes prioritāti, jo īpaši dzīvsudraba; ñemot vērā Ziemel̦valstu pieredzi un vietējos apstākḷus, potenciāli sagaidāmi dzīvsudraba kritisko slodžu pārsniegumi, (3) saskaṇā ar veiktajiem aprēḳiniem, paskābināšanās risks un eitrofikācijas risks pašlaik mežu apgabalos Latvijā ir salīdzinoši zems.

\section{Ивета Штейнберга. Расчеты критичных нагрузок и их картирование на лесных массивах в Латвии}

Критичная нагрузка (CL) - оценка воздействия одной или несколько загрязняющих веществ, которые могут вредить определенным чувствительным элементам окружающей среды, используя имеющиеся знания. При их расчетах учитываются не только параметры, характеризирующие целевую экосистему, но и долгосрочные изменения параметров, обеспечивающих ее экзистенцию и благополучие.

Моделирование CL лесных массивов Латвии проводилось с использованием VSD (Very Simple Dynamic model) модель. Лесные массивы выбраны как индикатор, характеризирующий территорию Латвии при оценке процессов подкисления и эвтрофикации.

Необходимые данные для расчета критичных нагрузок условно можно разделить на 5 основных блоков: (1) данные, характеризирующие качество почвы; (2) данные, характеризирующие состояние лесов и лесное хозяйство; (3) метеорологические показатели; (4) показатели, характеризирующие химический состав осадков и (5) слой моделирования клетки ЕМЕР. При моделировании получены результаты для 25562 лесных полигонов: (1) максимальная критичная нагрузка азота колебалась от 2419 до 25497 экв/(га×год); (2) максимальная критичная нагрузка серы колебалась от 734 до 8782 экв/(га×год). Калибровка модели произведена используя показатели химического состава почвы, дополнительно производилась сравнение трансграничных результатов.

Главные выводы: (1) учитывая неблагоприятное влияние соединении азота на разные экосистемы, желательно произвести подобного рода моделирование и для других чувствительных экосистем, например, болот; (2) моделирование критичных нагрузок тяжелых металлов можно считать приоритетом будущего, особенно ртути; учитывая опыт Скандинавии и местные обстоятельства, потенциально ожидается превышение критичных нагрузок ртути; (3) согласно произведенным расчетам, риски подкисления и эвтрофикации в настоящее время для лесных массивов Латвии относительно низкие. 